\title{
CATALOGUS
}

\section{der Javaansche, Balineesche en Madureesche handschriften van het Koninklijk Instituut voor de Taal-, Land- en Volkenkunde van Nederlandsch-Indië.}

\author{
Door Dr. H. H. JUYNBOLL.
}

In het $60^{\mathrm{e}}$ deel (1908) dezer Bijdragen (pag. 181-248) gaf Dr. Ph. S. van Ronkel een Catalogus van de 93 Maleische handschriften, die het Kon. Instituut bezit. Behalve deze Maleische zijn er echter ook 47 Javaansche, 2 Balineesche en 2 Madureesche handschriften en bovendien nog eenige Arabische, Tamil, Singhaleesche, Lampongsche, Rĕdjangsche, Makassaarsche, Tonseasche, Toumbulusche, Bugineesche en Bataksche handschriften, die echter hier niet beschreven zullen worden.

Gemakshalve heb ik de Javaansche handschriften in dezelfde rubrieken ingedeeld, als Prof. Vreede dit in zijn Catalogus der Jav. en Mad. HSS. der Leidsche Universiteitsbibliotheek heeft gedaan. Onder de brieven zijn ook enkele Sundaneesche $\left(\mathrm{n}^{\circ} 248^{\circ}\right.$ en 641), die echter te gering in aantal zijn, om er een afzonderlijke rubriek van te vormen.

Zooals Dr. van Ronkel reeds mededeelde, zijn de nummers 519_ 609 gekocht op de auctie van 27 April 1885 bij Martinus Nijhoff, terwijl sommige der andere hss, van Prof. Dr. P. J. Veth ten geschenke ontvangen werden. Van de later bij de verzameling gevoegde handschriften $636-645$ is de naam van den schenker bij de beschrijving vermeld. Behalve deze handschriften zijn er echter ook oudere, met een nummer beneden 501, waarmede de inventaris van Dr. Brandes begint. Deze zijn, hoewel onder andere nummers, gedeeltelijk vermeld in het $1^{\mathrm{e}}$ deel $\operatorname{der} 3^{\mathrm{e}}$ volgreeks van deze Bijdragen (1866), p. 213-216, waar van 57 handschriften de titels opgegeven worden.

Bij de beschrijving hebben wij in het belang der uniformiteit het systeem van Dr. van Ronkel in zijn Catalogus der Maleische handschriften van het Kon. Instituut gevolgd.

Alleen de verwijzing naar de catalogi van andere dan die der Leidsche handschriften is hier meestal weggelaten, omdat alleen de Jav. handschriften der Leidsche Universiteitsbibliotheek 
uitvoerig beschreven zijn en men hierin tevens de verwijzingen naar andere catalogi vindt.

Van de handschriften der Bataviasche en Londensche verzamelingen bestaan tot nu toe slechts opgaven van titels, doch nog geene beschrijvende catalogi.

Hoewel niet zeer omvangrijk, is de handschriftenverzameling van het Kon. Instituut toch van eenig belang, omdat men er de origineelen van enkele, later door Winter, Roorda of Meinsma uitgegevene teksten in aantreft. Ook onder de onuitgegeven HSS. zijn sommige door hun grooten omvang of rijke illustreering (bijv. $\mathrm{n}^{\circ}$ 522) niet van belang ontbloot. Vooral de beide groote HSS. 519 (Menak Sațit) en 520 (Basudewa) schenen mij gewichtig genoeg, om ze geheel te lezen. Ook het HSS. 521 (Babad Dipa Negara) is door zijn inhoud belangrijk.

\section{JAVAANSCHE HANDSCHRIFTEN.}

AfueELing I.

Epische geschriften.

I.

Pạ̣dawa rare en Ardjuna Wiwaha. (HS. 243).

$$
31 \times 19 \text { cM., } 94 \text { bl., } 19 \text { r. }
$$

Geheel in bruin leder gebonden, inlandsche band met overslag,

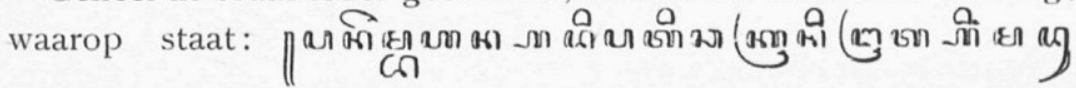

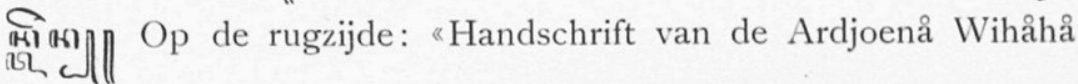

(sic), afkomstig van Panæ̌mbahan Adipati Tjåkrå-diningrat, van

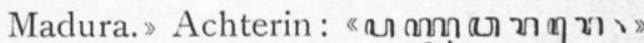

Dit HS. bevat twee verschillende gedichten, geschreven in Madureesch getint Oostjavaansch, hetgeen blijkt uit de voortdurende verwarring van $i$ en $c, u$ en $o$ enz. Bovendien is de taal, waarin het geschreven is, eenigszins ouderwetsch, zooals blijkt uit het begin:

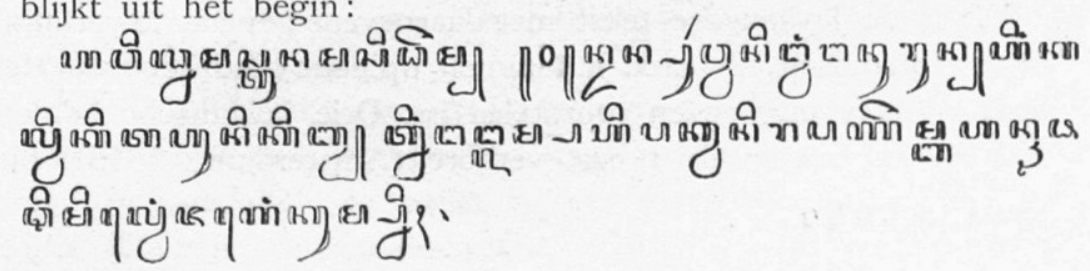


Het $1^{\mathrm{e}}$ gedicht, Pạ ḍawa ra re, dat loopt tot blz. 57, begint op blz. 2 met:

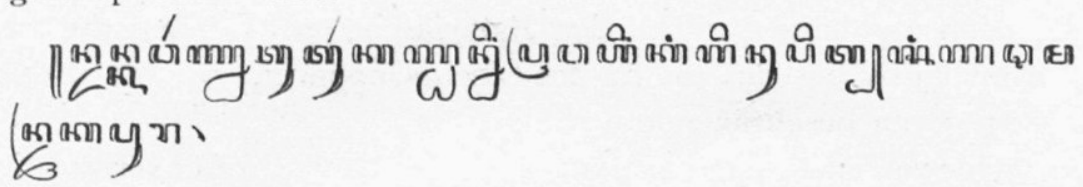

Zooals uit den titel blijkt, vormt de geschiedenis van de jeugd der Pa ṇ dawa's den inhoud.

Het begin komt, behoudens den vorm (in těmbang), geheel overeen met het door Roorda in 1869 uitgegeven en in 1879 door van der Vliet in deze Bijdragen (4 ${ }^{\mathrm{e}}$ volgr. III, blz. 273-329) vertaalde wajang-verhaal $\mathrm{P}$ a n d o e. Verder wordt de geboorte der Korawa's en Paṇ ḍwa's, hunne onderlinge twisten, het dobbelspel, de verbanning der Pạ̣dawa's naar Wirața, hunne ontmoeting met Arimba, het huwelijk van Bima met Arimbi en de geboorte van Gațotkatja over het algemeen evenals in het Mahābhārata beschreven. Dit gedeelte is gedateerd $22 \mathrm{Mukaram}$, zonder opgave van jaar.

Het slot (blz. 61-94) wordt gevormd door het bekende gedicht Ardjuna Wiwaha, dat door Gericke uitgegeven is met vertaling en aanteekeningen in deel XX der Verhandelingen van het Bataviaasch Genootschap. Deze tekst wijkt echter van de uitgave af.

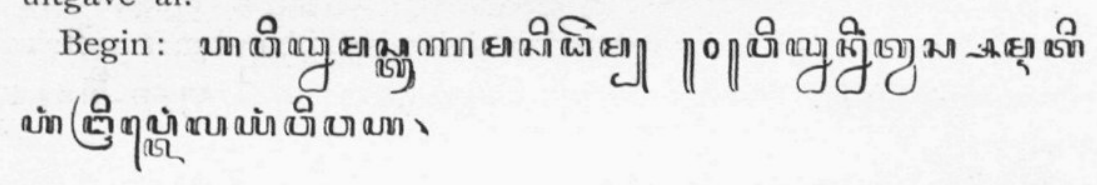

II.

\author{
R a m a I (HS. 566). \\ $33 \times 21$ cM., 78 blz., 31 r.
}

Voorin: "Romo van J. H. van der Palm, Soeracarta den $22^{\text {en }}$ November 1841.»Achteraan onder het einde: "De AspirantElève voor de Javaansche taal J. H. van der Palm, Soeracarta den 15 Maart 1842. . De omslag van Javaansch papier.

Dit is de Javaansche tekst met daarnevens geplaatste vertaling in 't Hollandsch, in twee kolommen op eene bladzijde, van den door Winter uitgegeven prozatekst in: Drie Javaansche heldendichten in Javaansch proza verkort (Amsterdam, 1845), blz.

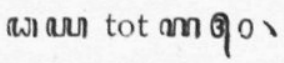


III.

R a m a II. (HS. 585).

$34 \times 21$ cM., 94 blz., 27 r.

Buitenop: Romo. Dit is de tekst en de vertaling in het Hollandsch van den door Winter uitgegeven prozatekst in: Drie Javaansche heldendichten in Javaansch proza verkort, blz. เง aภ - an 30、 Het is een net exemplaar van $n^{\circ} 566$ (II).

IV.

R a m a III. (HS. 606).

$19 \times 15 \frac{1}{2}$ cM. , 366 blz., 13 r.

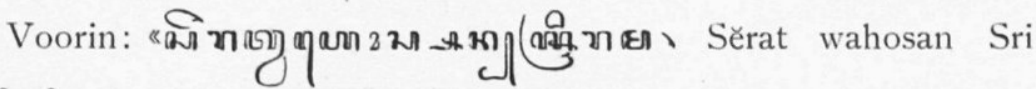
Råmå.»

Dit is de Nieuwjavaansche tekst in těmbang, uitgegeven door Winter in Verh. Bat. Gen. XX. Het is geheel in leder gebonden. Achterin staat met potlood: Jav. Sri Rama. Gekocht op de auctie van 27 April 1885 bij Martinus Nijhoff.

V.

B a su dewa. (HS. 520).

$34 \times 21$ cM., $2 \times 226$ blz., 16 r.

Geheel in leder gebonden, in inlandschen band zonder overslag. Voorin met potlood: "Geschiedenis van vorst Basoedewå, koning van Mandoerå, Kangså en Kresnå». Achterin met inkt:

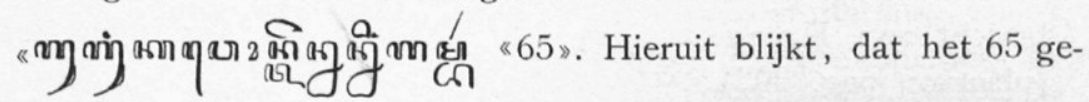
kleurde platen bevat. De inhoud van dit gedicht is als volgt:

In het begin wordt de geschiedenis van Basudewa en van de geboorte van Narayana, Kakrasana en Sumbadra verhaald op dezelfde wijze als in den lakon Arimbå, die door Dr. Hazeu in tekst en vertaling uitgegeven is in deze Bijdragen (6 $6^{\mathrm{e}}$ volgr. V (1898), p. 335-349 en $\left.371-388\right)$, doch hier uitvoeriger en in poëzie.

Er zijn echter enkele afwijkingen, bijv. Bas u d ewa's gemalin, die tijdens zijne afwezigheid door den děnawa Ugrawongså in zijne gedaante beslapen wordt, heet daar Maherah, doch hier $\mathrm{Kirmirah}$. Het slot van dien lakon, waar verhaald wordt, 
hoe Sĕmbadra aan Antagopa toevertrouwd wordt, komt hier voor op pag. 86 (zang VIII).

Verder is de inhoud als volgt:

De vorstin van Wiḍa ra Kaṇ da ng, die kinderloos is, schaakt een kind, dat later Sěntjaki wordt genoemd. Kongsa beveelt Lěbur Gongsa, om Kakrasana en Narayaṇa te zoeken. Dit wordt afgebeeld op pag. 102. De beide knapen komen bij den adjar Kipu (pag. 120). Op pag. 135 ziet men, hoe zij en hunne zuster Sĕmbadra twee děnawa's ontmoeten.

Van pag. 140 af wordt de geboorte der Pạ̣dawa's en Kurawa's en de dood van Pạ̣ ḍu beschreven. Op pag. 152 ziet men de vijf $\mathrm{Pa}$ a dawa's treurende over den dood van hun vader. Antagopa geeft aan Arya Prabu, die Kakrasana en Narayaṇa zoekt, zijn eigen kind, dat zeer veel eet (pag. 158). De beide knapen bestrijden twee buta's, hetgeen op pag. 192 wordt afgebeeld. Nu wordt verhaald, hoe de olifant Gokarṇa Narayaṇa en Sumbadra schaakt. Kakrasana gaat boete doen. De olifant brengt Narayạ naar zijnen leeraar Kapi Djĕmbawan, die hem herkent als eene incarnatie van $\mathrm{W}$ iṣṇ u en hem laat huwen met zijne dochter $\mathrm{Dj}$ ěmbawati.

De vorst van Magada hoort, dat de vorst van Ngastina, die met de prinses van Mandura gehuwd was, gestorven is, waarop hij $\mathrm{Ngastina}$ aanvalt. Bim a zegt tot $\mathrm{K}$ un ti, dat hij hem zal weerstaan. Ku n t i verlaat $\mathrm{Ng}$ ast in a. De blinde Dẹsța rata bestrijdt den vorst van Magada, genaamd Suramadẹṇ ḍa, zooals op pag. 289 is afgebeeld, en verslaat hem. Buta pěrung bericht aan Kongsa, dat $\mathrm{Naray}$ ṇa hem verslagen heeft (plaat op pag. 302).

In zang XXIX (pag. 307) begint eene nieuwe episode. In Ngalěngka heerscht Sasrawahana, de kleinzoon van Rawa ṇa (pag. 315). Hij brengt schatting aan Mondrapura. Zijn patih is Kombarawa, de kleinzoon van Kumbakar ṇa (pag. 316).

Eens ziet hij vele beenderen van reuzen liggen en ontsteekt in toorn, als hij hoort, hoe zijn grootvader door R a m a verslagen is. Om hem te wreken trekt hij tegen $\mathrm{Ngayodya}$ op (pag. 323, plaat). Daar heerscht Singgun Mas, wiens patih Palyagakandi van Sugriwa afstamt. Deze roept de hulp van Narayana in tegen Sasrawahana. Hij krijgt de kroon 
en den tjakra van $\mathrm{Rama}$. Hiermede gewapend doodt $\mathrm{Na}$ rayaṇa Sasrawahana (pag. 379). Daarop huwt hij dewi Pritiwi, eene incarnatie van Dewi Sri.

Ten slotte wordt verhaald, hoe de goden aangevallen worden door Pantjatnjana en hoe zij door Kakrasana geholpen worden. Deze doodt eerst den Naga Pasonta, den ouderen broeder van Pantjatnjana, door zijn slagtand uit te rukken, en daarna Pantjatnjana zelf. Ter belooning krijgt hij den Něnggala (ploegschaar), die uit die slagtand ontstaat. Hij wil zijnen broeder $\mathrm{Narayaṇa} \mathrm{en} \mathrm{zijne} \mathrm{zuster} \mathrm{Sĕmbadra}$ gaan zoeken en hoort van Bațara Guru, dat zij nog leven: Hier eindigt het HS. abrupt. De laatste woorden luiden:

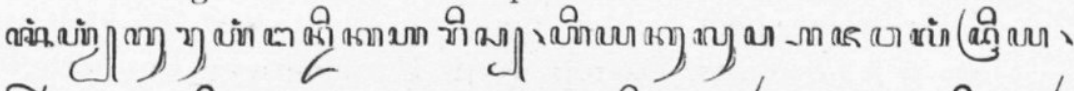

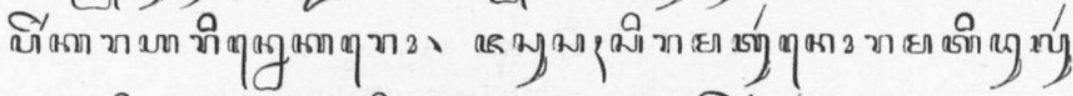

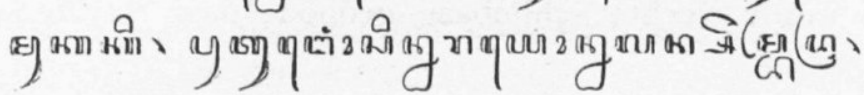

AFdeEling II.

Mythologie en legendarische geschiedenis.

VI.

Adji Saka (HS. 567).

$34 \frac{1}{2} \times 21$ cM., 119 blz. 21 r.

Achterin "Hadji Soko». Dit HS. bevat tekst en vertaling in het Hollandsch van het begin van de proza-omwerking van de Adji Saka door C. F. Winter (1857), overeenkomende met blz. an - 60 der uitgave. Het Javaansch links en de Hollandsche vertaling rechts. Vgl. Prof. Vreede, Cat. der Jav. en Mad. HSS. pag. 19, cod. 1835 en Dr. H. H. Juynboll, Suppl. op den Cat. der Jav. en Mad. HSS. II, pag. 431, cod. 119 Bijbelgenootschap.

$$
\begin{gathered}
\text { VII. } \\
\text { Menak Sațit (HS. 519). } \\
34 \times 21 \text { cM., } 214 \times 2 \text { blz. } 16 \text { r. }
\end{gathered}
$$

Dit HS. is in geheel leder gebonden, inlandšche band zonder

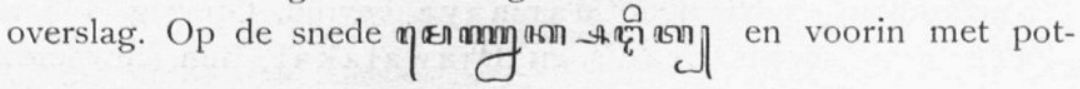


lood: "Geschiedenis van Menak Sațit.» Het bevat vele illustraties.

Het is van vrij groot belang, daar het begin eene episode van den Menak of liever van de uitloopers daarvan bevat, die tot nu toe onbekend was en zelfs in de rijke handschriftenverzameling der Leidsche Universiteitsbibliotheek ontbreekt. De inhoud is als volgt:

Nursewan zendt zijnen patih Bestak naar Djayengrana (Hamza), om te klagen, dat M ðdayin door onzichtbare dieven geteisterd wordt. Djayengrana verdenkt zijnen zoon Suwongsa (R ̌patmadja) hiervan en laat hem door Běstak gevangen naar Medayin voeren. Op pag. 24 ziet men, hoe hij door de troepen van M edayin doorschoten wordt.

Kilir voert hem echter door de lucht weg en stelt een ander in zijne plaats. Daarop wordt U marmay a van hetzelfde vergrijp beschuldigd en eveneens aan Nursewan uitgeleverd.

Ook hij wordt slechts schijnbaar gedood, daar Kilir ook hem wegvoert.

Nadat zoo de beide voornaamste helden verwijderd zijn, komen drie vorsten Pusĕr bumi (Mekka) belegeren, nl. Awur Djaman van Djungbiradji, Suwonda van Giling wěsi en Menak Sațit van Peret, op aanstoken van Nursewan (pag. 49).

Intusschen laat Kilir Marmaya en Suwongsa weder op aarde nederdalen. Suwongsa komt in Giling w̌si en huwt daar de Prabu kěnya en Ambar Manik, nadat zij zich tot den Islam bekeerd hebben. Op pag. 68 en 82 worden deze vorstinnen afgebeeld. Op pag. 113 ziet men: hoe Suwongsa met de Prabu kěnya op het wonderdier Singa djalma naar Arabië terugkeert.

Daar strijden de vorsten Lamdahur en Kewusnendar eerst met succes tegen de drie verbonden vorsten. Lamdahur overwint zelfs Awur Djaman en Suwonda, doch tegen Sațit zijn zij niet opgewassen. Op pag. 127 ziet men, hoe zijne setan's alle Arabische helden gevangen nemen. Zelfs Djayengrana kan hem niet overwinnen en vlucht met Marmadi en Marpindjung (pag. 133). Nu strijden de vorsten onderling om het bezit van Marpindjung en Sațit behaalt de overwinning. Ook de Prabu Rara wordt door de setan's aangevallen, doch door Marmaya bevrijd. Op pag. 148 ziet men, hoe zeven setan's en Djawalakal, hun aanvoerder, 
Marmaya bestrijden en op pag. 152, hoe zij hem binden. Ten slotte overwint echter Marmaya de setan's en bestrijdt dan Sațit, zooals men op pag. 164 ziet. De Prabu Rara komt hem te hulp en strijdt, gezeten op den Singa djalma, tegen Tațit, die den Wilmana Djěgendra berijdt (pag. 168). Ma rma y a doodt eindelijk $\mathrm{T}$ a țit met een hamer (p. 172). Dan gaat hij de Arabische vorsten bevrijden, die in Mědayin gevangen zijn, en tevens Nursewan en B ěstak straffen. Op pag. 184 ziet men, hoe Lamdahur rijdt op Nursewan en Kemar op Běstak, die door Marmaya voortgezweept wordt.

Marmaya en Suwongsa gaan Djayengrana en Umarmadi zoeken en veranderen zich daarbij in buta's, in welke gedaante zij hen bestrijden, totdat zij elkaar herkennen (pag. 196).

$\mathrm{Nu}$ wordt verhaald, hoe Dewi Kuraisin van $\mathrm{Ngadjĕrak}$ het rijk Mědayin aanvalt, omdat zij meent, dat de Arabische vorsten tegen $\mathrm{Hamza}$ zijn opgestaan (pag. 203).

Haar leger van djim's verslaat Kemar, Lamdahur en zelfs Suwonda en Awur Djaman (pag. 213). Op pag. 214 ziet men, hoe de Prabu Rara van Giling wesi de djim's verslaat en op pag. 220, hoe zij $\mathrm{Ku}$ rais in bestrijdt. Marmaya komt echter tusschen beiden en deelt haar mede, dat $\mathrm{Kuraisin}$ eene van hare schoonmoeders is. Hamza keert daarop met de zijnen naar M ̌kah terug.

Van pag. 234 af gaat het verhaal over tot de geschiedenis van Lokayanti, den vorst van Dulang Mas. Daar deze episode reeds beschreven is in het $2^{\text {e }}$ deel van mijn Supplement op den Cat. der Jav. en Mad. HSS. der Leidsche Universiteitsbibliotheek (pag. 29-32) ${ }^{1}$, zal ik er hier niet verder over uitwijden. Alleen zal hier op de afwijkingen gewezen worden.

Op pag. 261 ziet men, hoe een bode van Lokayanti van Djayengrana (Hamza) de uitlevering van Suwongsa eischt. Hier ontvangt echter die bode onmiddellijk een weigerend antwoord, terwijl in het Leidsche HS. 4027 (pag. 7) $\mathrm{Hamza}$ zijn zoon eerst verbant. De prinses van M ésir heet hier Su ryawati (pag. 278), dus evenals in het Leidsche HS. 4003 , terwijl zij in cod. $4027 \mathrm{Tj}$ andrawati heet. Hier is Murdangkara de vorst van Ngaběsi, terwijl in cod. 4027 Murdeng-

1 Vgl. ook de Mad. redactie van den Lukayanti, beschreven in deel I (pag. 21) van hetzelfde Supplement. 
kara de vorst van Un ěngan is. Op pag. 296 verandert Suwongsa zijn naam in Kĕrĕnda Sělaka en Umarmadi den zijnen in Warku Dobrah. In cod. 4027 luiden deze namen Krědap Salaka en Brěgu Dombras, terwijl in cod. 4003 de eerste naam Kĕrda Salaka luidt. De man, die voor Suw ong sa wordt aangezien, heet hier (pag. 300) Sarimpang, doch in cod. 4027 Srimping. De palmwijntapper, die daar P anderesan heet, wordt hier Deres genoemd (pag. 306). Overigens komt de inhoud vrij wel overeen tot pag. 384 .

Op pag. 385 begint weder eene nieuwe episode, die in de Leidsche HSS. ontbreekt. Hier wordt verhaald, hoe Embadjati, het land van $\mathrm{Djanggi} \mathrm{Kalarètna,} \mathrm{overstroomd} \mathrm{wordt.}$

De vorst droomt, dat de overstrooming zal ophouden, als hij Nursewan gevangen neemt.

Daarom zendt hij twee djim's naar Médayin, die in de gedaante van Widyadari's Nursewan en Běstak schaken. Als hij dit verneemt, komt $\mathrm{Hamza}$ zijnen schoonvader te hulp. Op pag. 406 is Garuḍa in gesprek met Djayengrana (Hamza) afgebeeld. Omdat hij te oud is, zendt Hamza Marmaya, die Nursewan en Běstak bevrijdt, na alle djìm's, die hen bewaken, door een toovermiddel in slaap te hebben gemaakt (pag. 409).

De patih van Djanggi Kalarětna ontrukt echter Nursewan en Běstak weder aan Marmaya, die door Marmadi bespot wordt. Zij. komen onder een boom en hooren daar, hoe de djim Mukadar tot Mukadir zegt, dat al wie onder dien boom komt, diens wonden zullen genezen. Mukadir vraagt daarop, wat de naam is van dien boom.

Hier eindigt het HS. abrupt. Men ziet uit bovenstaande beschrijving, dat de naam Menak Sațit alleen op het eerste gedeelte betrekking heeft. Daarop volgt de Dulang Mas en Lokayanti, terwijl uit het abrupte slot niet blijkt, welke episode op pag. 385 aanvangt.

De spelling is over het algemeen de Oostjavaansche. 
Afdeeling III.

\section{Geschiedenis.}

VIII.

Babad Tanah. Djawi I. (HS. 237).

$34 \frac{1}{\longleftarrow} \times 21$ cM., 873 blz., 27 r.

Voorin: "Herkomst???» en "Babad eerste stuk».

Over dit HS. zegt Dr. Brandes in zijn Register op de prozaomzetting van de Babad Tanah Djawi (Verh. Bat. Gen. LI). Inlichtingen, pag. 9* "De copie (?) van de door Meinsma uitgegeven Babad Tanah Djawi, $1^{\mathrm{e}}, 2^{\mathrm{e}}$ en $3^{\mathrm{e}}$ stuk (a en b).»

Het eerste stuk bevat $139 \mathrm{blz}$. folio en komt overeen met het eerste stuk van Meinsma's editie der Babad Tanah Djawi (tot pag. z祭)

Het tweede stuk, groot 147 blz. folio, heeft tot opschrift: "verbeterde Babad, $2^{\mathrm{e}}$ stuk» en loopt tot pag \& 60 , r. 3 v.o. der Babad-uitgave.

Het derde stuk, groot 150 blz. folio, met opschrift: "verbeterde Babad: $3^{\text {e }}$ stuk», begint met pag. $63 / \varsigma$, nieuwe alinea der Babad-editie, doch zonder q

Het vierde stuk, groot 357 blz. folio, met opschrift: "verbeterde Babad, $4^{\mathrm{e}}$ stuk, » sluit zich onmiddellijk aan het slot van het $2^{\mathrm{e}}$ stuk aan en begint dus met pag. $c^{6} b_{0}$, r. 3 v.o. der Babad-uitgave.

Het vijfde stuk, groot 80 blz. folio, heeft tot opschrift: "Babad, 5 e stuk. De beginwoorden luiden: ๓ ๆ

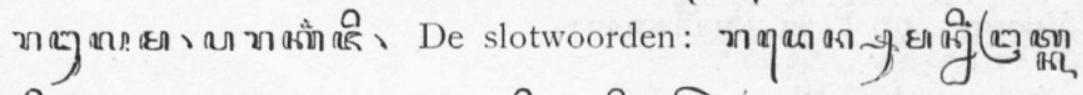

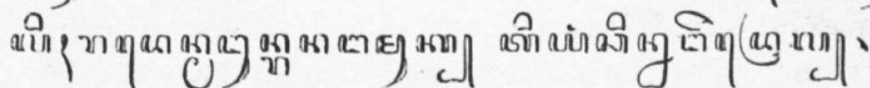

IX.

Babad Tanah Djawi II. (HS. 237a).

$34 \frac{1}{2} \times 21$ cM., 328 blz., 27 r.

Voorin: "Javaansche Babad in proza. Eerste stuk. "

Over dit HS. zegt Dr. Brandes, 1. c.: « Het origineel van n०237 of die copie, $1^{\mathrm{e}}$ tot en met het begin van het $5^{\mathrm{e}}$ stuk.» 
Het eerste stuk bevat 172 blz. folio en komt overeen met het eerste stuk van Meinsma's Babad-uitgave; het tweede stuk, dat 156 blz. folio bevat, komt overeen met het tweede stuk dier uitgave.

X.

Babad Tanah Djawi III. (HS. 562).

$33 \times 21$ cM., 107 blz., 27 r.

Voorin: "Babad» en "Senopati».

Dr. Brandes vermeldt dit HS. 1. c. pag. $9^{*}-10^{\circ}$. Het grootste gedeelte ervan is uitgegeven door den heer G. P. Rouffaer onder den titel: "De val van de kraton van Padjang door toedoen van Senapati ( $†$ 1586), volgens de Babad Tanah Djawi» in deze Bijdragen (deel L, pag. 284-314). Het is een copie, gemaakt door den een of anderen klerk te Soerakarta(?) naar een goed origineel. Het komt overeen met blz. 129-211 van de editie van Meinsma (op den omslag staat ten onrechte 129_210, zooals ook Dr. Brandes, 1. c. heeft). Naast den Javaanschen tekst staat eene gedeeltelijke vertaling in het Hollandsch van blz. $129=203$ (niet 202, zooals op den omslag staat en zooals Brandes 1. c. geeft).

Het door den heer Rouffaer uitgegeven gedeelte eindigt hier op blz. 66. Hier is eene groote gaping, tot blz. 82, daarna weder eene van blz. 86-94, terwijl op blz. 98 de vertaling geheel ophoudt. De Javaansche tekst loopt echter geregeld door.

XI.

$\mathrm{Babad}$ tĕmbang I. (HS. 552).

$33 \times 20,5$ cM., $226 \times 2$ blz., 18 r.

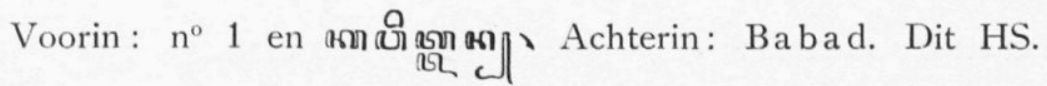
begint met den dood van Bimanyu en eindigt in het gevecht van Senapati met Kanitèn (zie Babad Tanah Djawi, pag. ภา

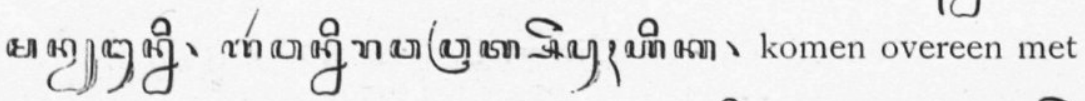

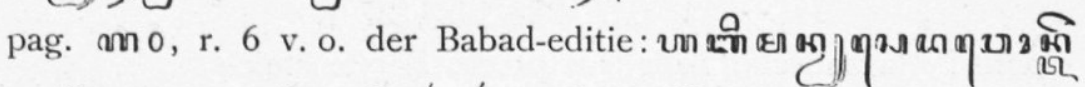

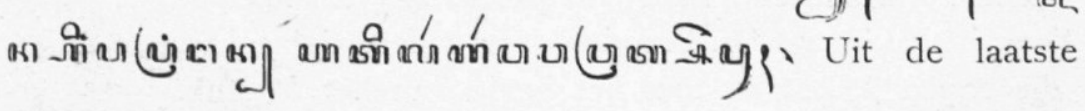


strophe blijkt, dat dit HS. geschreven is 27 Maart 1860. Het bevat o. a. de geschiedenis van Bandjaran Sari en van het kanon Sertoma. Het is ingebonden in een inlandschen roodlederen band.

De beginwoorden der eerste 6 zangen komen overeen met die van de versie in 287 zangen, waarvan Dr. Brandes de beginwoorden geeft op pag. 1*-9* van zijn Register op de Babad Tanah Djawi (Verh. Bat. Gen. LI, $4^{\mathrm{e}}$ stuk). Van zang 7 af wijken de beginwoorden der zangen achter af.

\section{XII.}

$\mathrm{Bab}$ ad těmbang II. (HS. 239).

$34 \times 22$ cM., 640 blz., $20 \mathrm{r}$.

Voorin de volgende mededeeling van Mr. S. Keyzer, 1863: "Fragmenten van geschiedenis of levensbeschrijving van Javasche vorsten, beginnende met de fabuleuze tijden van $\mathrm{Adji}$ Såka en midden in een volzin afbrekende in de tijden van Pangéran Pugerr. Herkomst niet bekend.»

De 10 eerste pagina's bevatten woorden om cijfers uit te drukken (tjandra sëngkala), met het volgende onderschrift: "Alle de hiervoren staande zijn maar Hoogdalmsche woorden, dewelke in oude tijden als cijffergetallen in de Javaansche Historieboeken, zijn gebruikt geworden, dus ik dies vertaaling onnoodig geoordeeld heb.» Op pag. 11: «Hier begind de waare inhoud van de leevensbeschrijvingen der Javasche vorsten.»

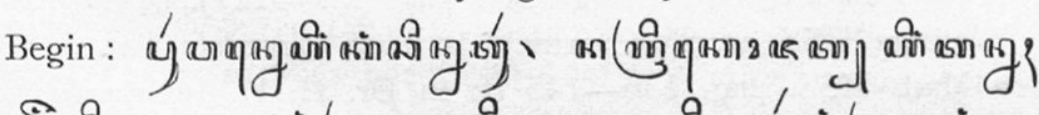

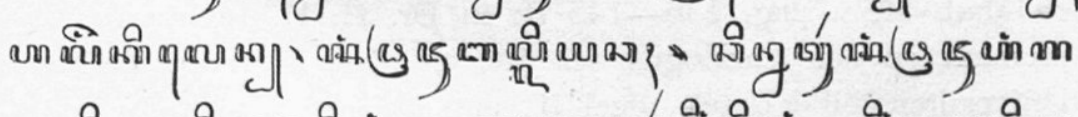

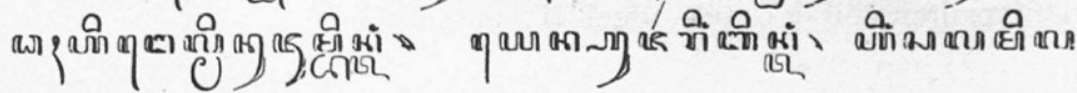
धिๆ㕰 Op pag. 24 is reeds sprake van Adji Saka, die in 525 Java onderwierp.

Het slot komt overeen met pag. Зал ил , r. 14 der Babadeditie, waar verhaald wordt, hoe Anggawangsa of Djayengrana met Tjakraningrat naar Pangeran Pugěr

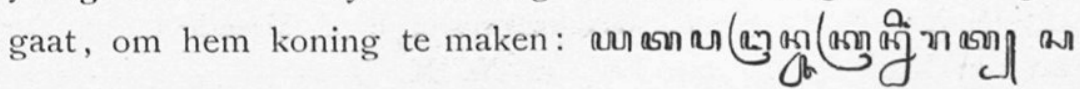

Dl. 69 . 


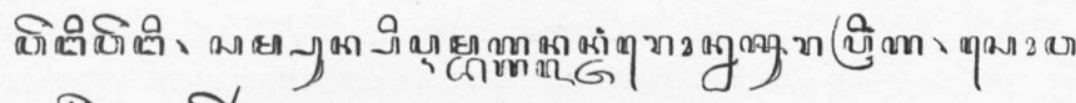

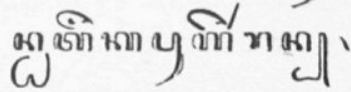

XIII.

Babad Dipa Něgara. (HS. 521)

$33 \times 21,5$ cM., $200 \times 2$ blz., 17 r.

Geheel in leder gebonden, inlandsche band zonder overslag.

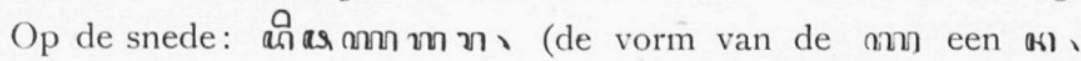
verlengd met een $m$ ). Voorin met potlood: "De oorlog met diepo negoro». Achterin een paar han atjaraka. Met illustraties.

Prof. Vreede zegt in zijn Cat. der Jav. en Mad. HSS. der Leidsche Universiteits-bibliotheek, pag. 145, n. 1 van dit HS.: "Het is niet onaardig geillustreerd, doch vol schrijffouten. Behaive het allereerste begin, waaruit blijkt, dat het een afschrift is van een babon (legger) in 't bezit van Mas Ngabèhi Soera Něgara, patih van Semarang, en de laatste 40 bladzijden, die nog al afwijken, heeft de redactie zeer veel gelijkheid met cod. 1823 (der Leidsche Universiteits-bibliotheek). Het is groot $200 \times 2$ blz. folio, doch zeer wijd uiteen geschreven en loopt niet verder dan tot ongeveer blz. 130 van cod. 1823.

Verder vergelijke men over de Babad Dipa Nĕgara: T. Roorda, Verhaal van de oorsprong en het begin van de opstand van Dipå Negårå, volgens een Javaansch handschrift (in deze Bijdragen, $2^{\mathrm{e}}$ volgr. III, pag. 137-227).

Andere HSS. worden vermeld in Prof. Vreede's Cat. der Jav. en Mad. HSS. pag. 136-145 en in Dr. H. H. Juynboll's Supplement op den Catalogus der Jav. en Mad. HSS. der Leidsche Universiteits-bibliotheek, deel II, pag. 94.

\section{XIV.}

Babad Sẽngkala (HS. 619).

$32 \times 21 \mathrm{cM}, 5$ blz., $20 \mathrm{r}$.

$\mathrm{Babad} \mathrm{S} \check{n} \mathrm{gkala}$, bevattende chronogrammen (s ěngkala) van het Javaansche jaar 1 (Adji Saka) tot 1584. Dit HS. komt overeen met het eerste gedeelte van cod. 1859 der Leidsche Universiteits-bibliotheek, beschreven in Prof. Vreede's Cat. der Jav. en Mad. HSS. pag. 147, $n^{\circ}$ XCIX. 


\section{XV.}

Babad Kartasura. (HS. 522).

$$
43 \times 27 \text { cM., } 25+156 \text { blz., } 20 \text { r. }
$$

Geheel in rood leder met verguldsel gebonden, vermoedelijk inIandsche band, zonder overslag. Voorin op een etiket: 102. Iets verder: F. G. Valck. Op drie vellen postpapier, groot formaat, vindt men inliggend van de hand van $\mathrm{C}$. F. Winter Sr. ${ }^{1}$ eene beschrijving van het geschrift, dat voor de eerste helft bestaat uit inlandsche plaatomramingen (van symbolieken aard?) met bijgaanden, ingeschreven tekst, waarin zoogenaamde pratjekan's. Het aantal der platen bedraagt 22. Op het zevende "bloemwerk» staat in de pratjekan de datum van het begin opgenomen: Vrijdag Kliwon 9 Mulud Dal, siněngkalan paṇdita kěkalih ardi tunggal (A. J. 1727), welke datum - als men uitgaat van 1 Sura Dal $1727=$ Zondag Paing 25 Mei 1800, en verder $\mathrm{Dal}$ op Solosche onregelmatige wijze tellend gelijkstaat met Vrijdag Kliwo n 1 Augustus 1800. Toch ontstond de onafhankelijke Paku-Alaman eerst 17 Maart $1813^{2}$. Op een $23^{e}$ blad volgt de titel van het boek: Kangdjĕng Kyahi Djati Pusaka. Op het $24^{\text {e }}$ blad begint een geslachtslijst, aanvangende met $\mathrm{Adam}$ en eindigende met Paku Alam I. De (niet voltooide) tekst, die dan volgt, is $153 \mathrm{blz}$. lang, en is een babad (in termbang), samengesteld door (of voor) Paku Alam, en loopende van Mangkurat Agěng (Tĕgal Wangi) tot op het susuhunan worden van Pangeran Pugěr (Pakubuwana I).

Prof. Vreede spreekt in zijn Cat. der Jav. en Mad. HSS. der Leidsche Universiteits-bibliotheek (pag. 146, n. 2) vrij uitvoerig over dit HS. Hij zegt o. a.:

"Niet onmogelijk is het, dat dit hs. hetzelfde is als waarvan gesproken wordt boven in de Babad Bedah Jogja blz. 132.

Immers het is een prachtexemplaar en volgens mededeeling van Dr. Wijnmalen aangekocht uit de nalatenschap van prins Hendrik. Vóorin staat de naam F. G. Valck (dezelfde, die omstreeks 1835 resident van Jogja was?). De eerste illustratie's stellen voor perioden uit de (gewijde) geschiedenis van den Mohammedaanschen held Ambyah (zie Ménak), daarna bevatten zij lofspraken op de Javaansche Vorsten, te beginnen met Panem-

1 Dat dit zoo is heeft de heer G. P. Rouffaer herkend.

2 Opmerking van den heer G. P. Rouffaer in den Inventaris. 
bahan Sénapati; het laatste "bloemwerk» behelst eenige lofspraken op Pakoe Alam I.

Daarna bevat het hs. een geslachtsboom van Adam af tot op denzelfden Pakoe Alam.

Eindelijk een stuk van 150 bladzijden tekst, beginnende met het uiteinde van Amangkoerat I, de zedelessen van dezen (onzedelijken) vorst aan zijn zoon (later) Mangkoerat Mas, de rebellie van Pangéran Poeger, en eindigende met de verheffing van dezen tot vorst met den titel van Pakoe Boewana I. Het verhaal werd volgens den schrijver opgesteld door den Pangéran Pakoe Alam.»

Dit HS. is een copie naar het origineele hs., dat ter Pakualaman berust en bij hooge uitzondering in Jan. 1903 vandaar ter tentoonstelling ter eere van den Prins Ruprecht van Beieren in het Residentie-huis (res. Couperus) tijdelijk werd overgebracht. Naar de "lampah pitoelas» [ $=$ fol. 16 in ons HS.] maakte toen Mej. M. Tonnet ter plaatse in Jogja een foto, welke in Maart 1906 door haar in de Koloniale Bibliotheek werd geconstateerd volkomen en precies overeen te stemmen met dezelfde "lampah pitoelas» in ons hs. ${ }^{1}$

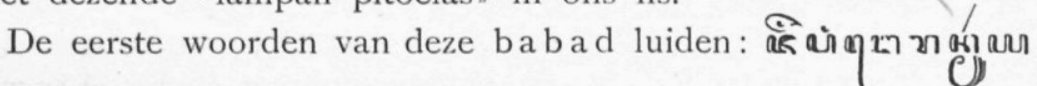

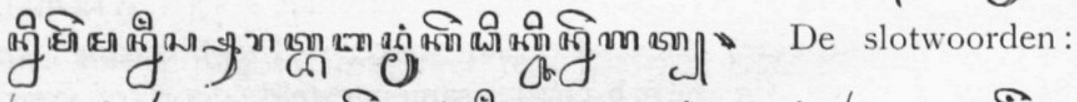

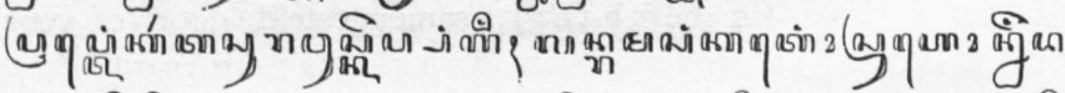

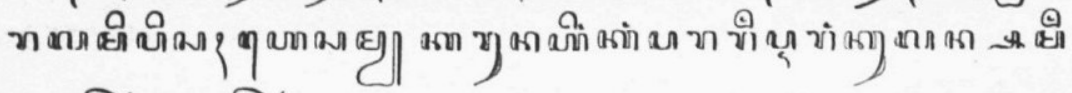

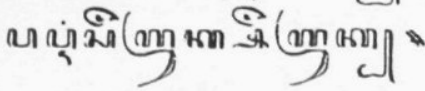

AFdeELING IV.

Romantische verhalen.

XVI.

Pandji gandrung Angreni. (HS. 421).

$19 \times 16$ cM., 185 blz., $11 \mathrm{r}$.

Dit HS. is hetzelfde, dat door T. Roorda in 1869 als het derde van de Wajang-verhalen Pålå-Sårå, Paṇḍoe en Raden-Pandji uitgegeven is (p. gob tot p. a $g^{a n}$ ).

1 Opmerking van den heer G. P. Rouffaer in den Inventaris. 
Het is wel de moeite waard, hierop de aandacht te vestigen, daar Dr. Gunning, die van deze uitgave een tweede editie bezorgde, in deze Bijdragen ( $6^{\mathrm{e}}$ volgr. I, pag. 165) zegt: "Te bejammeren is het, dat bovengenoemd handschrift spoorloos verdwenen schijnt te zijn, zoodat wij niet meer kunnen nagaan, of Prof. Roorda een alleszins getrouwe kopie van het oorspronkelijke geleverd heeft».

Uit Roorda's voorbericht blijkt, dat dit HS. uit Grissee afkomstig is en dateert uit het jaar 1860 , dat het net geschreven is en met weinig fouten, zoodat bijna alleen de spelling en de interpunctie te verbeteren waren.

Waar in Roorda's uitgave Javaansche cijfers voorkomen, vindt men in het HS. Europeesche cijfers, bijv. pag. 205 , r. 3 v. b.: ชท an 0 m hier: 1101.

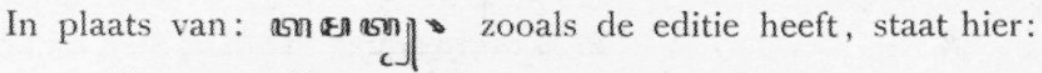

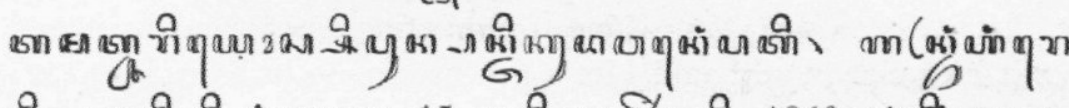

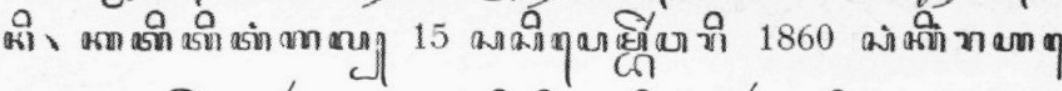

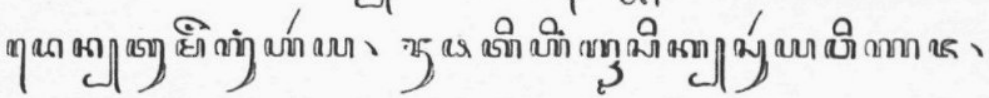

Hieruit blijkt, dat het 15 Februari 1860 door raden tumĕnggung arya bupati van Grěsik, Surya Winadja geschreven is.

\section{XVII.}

Pandji klajan Tundjung Seta. (HS. 422).

$$
19 \times 16 \text { cM., } 100 \text { blz., } 13 \text { r. }
$$

Dit is het origineel van het tweede der door $T$. Roorda in

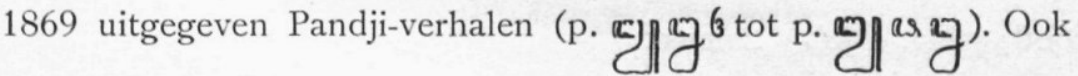
hier staat na het jaartal 1860 , waarmede de editie eindigt, de

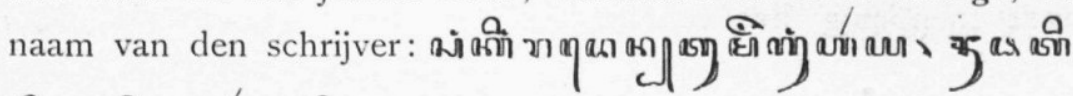

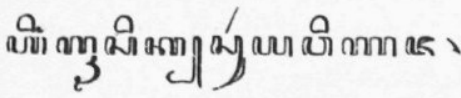

XVIII.

Damar Wulan. (HS. 636).

$22 \times 34 \frac{1}{2}$ cM., 202 blz., 18-27 r.

Omtrent dit HS., dat in Juni 1911 van Mr. Grashuis aan- 
gekocht is, deelt de vroegere eigenaar het volgende mede: "Deze Javaansche Damar Woelan is afkomstig uit het Cheribonsche en is het laatst, voordat hij in handen van een Europeaan kwam, het eigendom geweest van een Chinees. De ouderdom is te schatten op 70 à 80 jaren. De geïllustreerde Damar Woelan ontleent zijne beteekenis en waarde aan de illustraties.

Deze illustraties zijn gedeeltelijk gekleurd, gedeeltelijk penof potloodteekeningen met of zonder bijschriften, bijv. op blz. 23 Sabda palon, Andjasmara en Damar Wulan, op pag. 26 Lajang Setra en Lajang Kumitir, op pag. 38 Menak Djingga, Angkat buta en Kotbuta enz. De beginwoorden der zangen komen over het algemeen overeen met die, opgegeven door Dr. Brandes in zijne Beschrijving der Jav. Bal. en Sasaksche HSS. van Dr. van der Tuuk, I, pag. 216. Het HS. eindigt met Damar Wulan's overwinning van Lajang Setra en Lajang Kumitir. Zijne ontmoeting met zijne broeders wordt hier niet in verhaald. Het is geschreven op Javaansch papier.

XIX.

Djaka Salewah. (HS. 551).

$32 \times 20$ cM., 70 blz., 21 r.

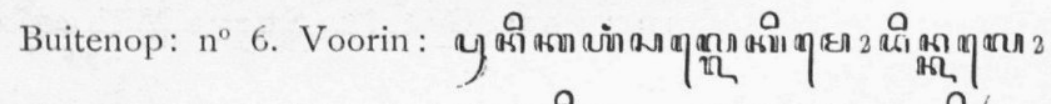

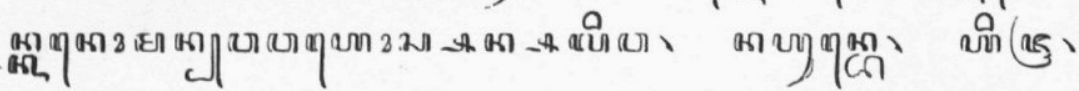
an $\mathrm{g}^{60}$ * Dit jaarcijfer (1240) is gewijzigd tot an 006 (1004)

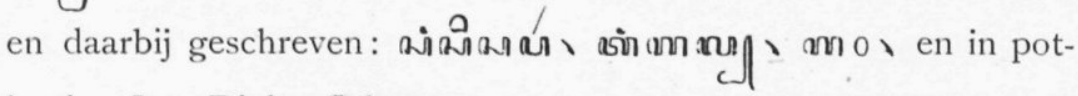
lood: "Jav. Djoko Salewo.»

Op de keerzijde van de bladzijde, waarop de tekst begint, vindt men nog het een en ander bijgeschreven en, met den nagel(?), een paar wajangfiguren ingekrast; om het begin eenig bloemwerk. Gaandeweg wordt de hand, die eerst vrij slecht is, beter. Het schrift en de spelling zijn eigenaardig; de wignjan's worden verzuimd en gebezigd als pada lingsa.

Sommige letters, zooals de aardig geschreven. Het HS. schijnt afkomstig te zijn uit Oost-Java.

Dit Javaansche gedicht is onvolledig. Andere HSS. bezit de 
Leidsche Universiteits-bibliotheek (cod. 1830, beschreven in Vreede's Cat. der Jav. en Mad. HSS. pag. 186-188, cod. CXXIV) en het Ned. Bijbelgenootschap (cod. 152, beschreven in deel II, pag. 80 van mijn Suppl. op den Cat. der Jav. en Mad. HSS. cod. CMLXI).

AFDEELING V.

Dramatische werken.

$\mathrm{XX}$.

$$
\begin{gathered}
\text { Palas ara. (HS. 564). } \\
32 \frac{1}{2} \times 20 \text { cM., } 196 \text { blz., } 17 \text { r. }
\end{gathered}
$$

Geheel in rood leder gebonden. Voorin: $G 4^{a}$, Geschenk van den Regent van Poerbålinggå, Residentie Banjoemas, Raden Toemenggoeng Dipå Koesoemå, ten behoeve der boekverzameling van het Koninklijk Instituut voor de Taal-, Land- en Volkenkunde van Neerlandsch-Indië, verzonden 7 Junij 1858».

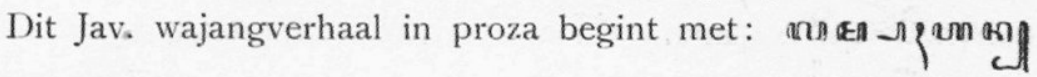

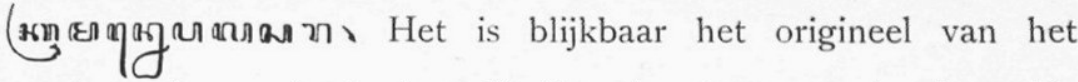
eerste wajangverhaal, door T. Roorda uitgegeven in zijne "De wajangverhalen Pålås årå, Paṇdoe en Raden Pandji» ('s Gravenhage, 1869), blz. ๗ -

Het is keurig geschreven en de beide eerste bladzijden zijn met vergulde en gekleurde lijsten, randen en bloemenguirlandes versierd. De namen der sprekende personen zijn, als het goden geldt, in het midden van drie concentrische cirkels geplaatst, b.v. Betțara Narada en Bettara Guru. De beide laatste bladzijden zijn alleen met penteekeningen versierd.

AFdEELING VI.

Godsdienstige werken.

XXI.

Ngelmi Makripat Sědjati. (HS. 639).

$20 \times 16$ cM., 100 blz., 24 r.

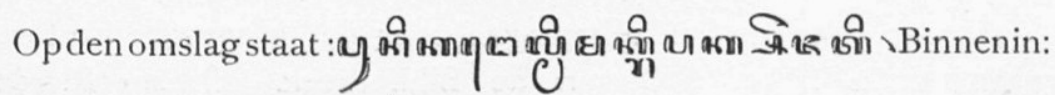


"Ngelmi makripat sědjati door Radhen arjo Poerbo Koesoemo te Pasoeroean.»

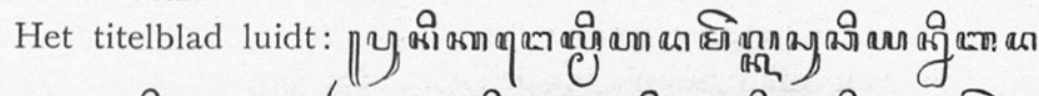

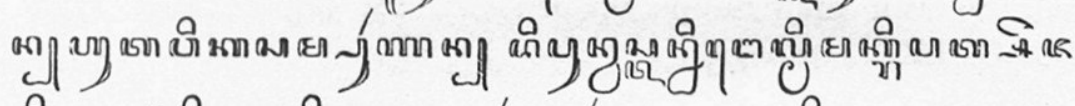

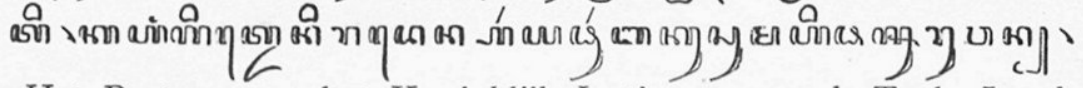
"Het Bestuur van het Koninklijk Instituut voor de Taal-, Landen Volkenkunde van Nederlandsch Indië aangeboden door J. H. J. Siegal, laatstelijk assistent-resident van Keboemen. Thans met verlof te 's-Gravenhage. 6 Aug. 1903.»

Het is een werk over mystiek. Het begin handelt over het wezen van den dad en is ontleend aan den Kitāb Hidāyatu'lgaib. De eerste woorden luiden:

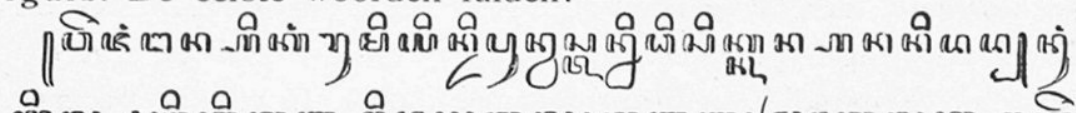

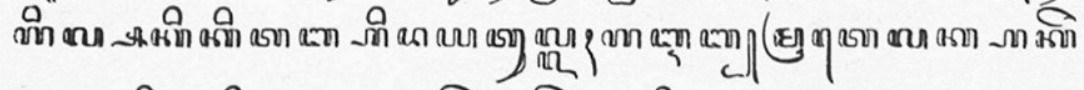

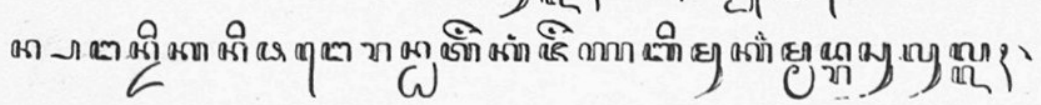

XXII.

Hadji Ripangi. (HS. $248^{\text {b }}$ ).

$34 \times 22$ cM., 28 blz., 32 r.

Vertaling van een Arabisch boek van $\mathrm{Hadji} \mathrm{Ripangi,} \mathrm{in}$ het Javaansch en laag-Maleisch naast elkaar. De titel luidt:

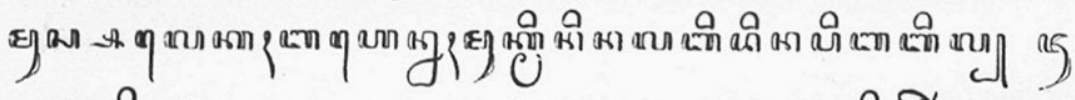

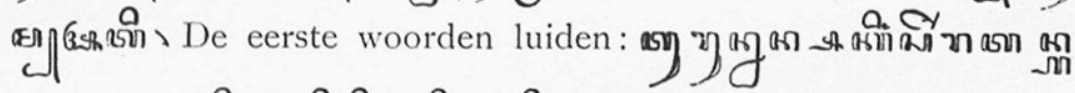

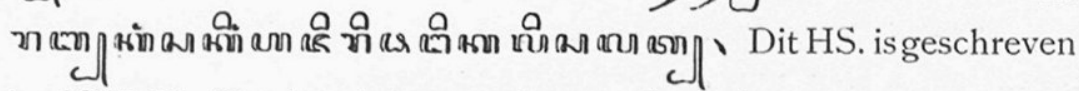
in $1267 \mathrm{H}$. Het handelt vooral over de salāt.

AFDEELING VII. Wetboeken.

XXIII.

Javaansche wetten. (HS. 248 ).

$22 \times 14 \mathrm{cM}$.

"Handschriftelijke aanteekeningen over de Javaansche wetten, gevonden in $\mathrm{n}^{\circ} \mathrm{r}, 103$ van de Bibliotheek, zijnde. «R. de 
Filliettaz Bousquet. Korte beschrijving van de Javaansche Regtbanken (1843).» Dit HS. bevat inhoudsopgaven van den A ng g ěr Gunung, Anggěr Agěng, Anggěr Sadasa en Nawala Pradata, ook variae lectiones. Het is in 1901 van de firma Nijhoff terug ontvangen uit den boedel van N.N.

\section{AFdeELING VIII.}

\section{Varia.}

\section{XXIV.}

Hollandsch-Javaansch woordenboek. (HS. 556).

$$
30 \frac{1}{2} \times 20 \text { cM., } 609 \text { blz. }
$$

Hollandsch-Javaansch woordenboek, gebonden in half leder, van denzelfden oorsprong als het Jav. Hollandsche Woordenboek, opgenomen onder $\mathrm{n}^{\circ} 523$.

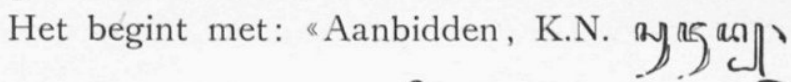

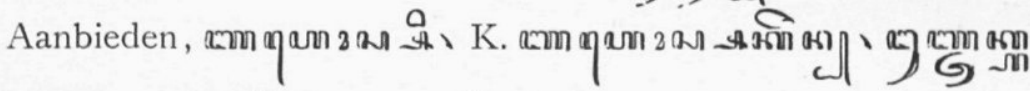

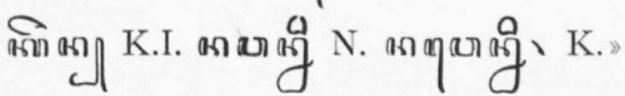

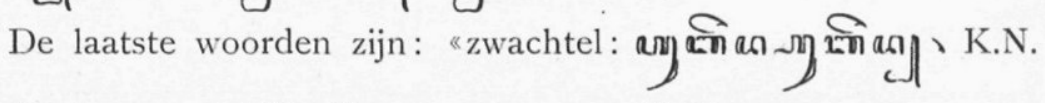

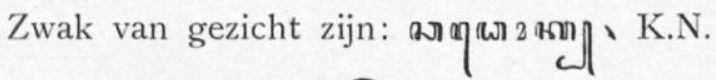

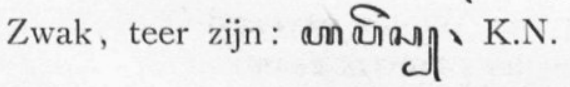

Zweven in de lucht: aлmaĩ a K.N.»

\section{XXV.}

Javaansch-Hollandsch woordenboek. (HS. 523).

$$
40 \frac{1}{2} \times 25 \text { cM., } 838 \text { blz. }
$$

Javaansch-Hollandsch woordenboek. Hier en daar zijn verwijzingen of aanhalingen naar en uit enkele teksten (Adji Saka, Nawa Rutji, Babad) bijgeschreven. Het is geheel in leder gebonden.

De herkomst is onbekend. 


\section{XXVI.}

Brieven. (HS. $248^{\circ}$ ).

$34 \times 22 \mathrm{cM}$.

Deze bundel bevat Sundasche, Javaansche en Maleische brieven, o. a. een Sundasch proces-verbaal met vertaling en een Sund. brief van 25 Februari 1874. De 23 Javaansche brieven zijn gedateerd van 1870-1872. Het zijn dienstbrieven van wédana's aan controleurs, waarvan twee zeker en misschien ook de 21 andere geadresseerd zijn aan den heer Wiselius, controleur van Lamongan.

\section{XXVII.}

Brieven (HS. 539).

Twaalf Javaansche brieven aan de heeren H. C. Humme en J. L. Rhemrev, gedateerd van 1870 tot 1881. De inhoud is onbeduidend. In den eersten vraagt de schrijver een zilveren medaille, omdat hij negen geschriften aan den Directeur van O. E. en N. geschonken heeft. In den derde verzoekt hij, in rang verhoogd te worden. Drie handelen over het koopen van een Bataksch paard enz.

\section{XXVIII.}

Brieven (HS. 583).

Twee Madeische en zeven Javaansche brieven. De Jav. brieven zijn gericht aan baron de Kock, resident van Jogyakarta en gedateerd 1339 H. $=1851$ A.D. of 1779 A.J. Bij den laatste is eene Nederlandsche vertaling van Winter gevoegd.

\section{XXIX.}

\section{Brieven (HS. 641).}

In een bundeltje HSS., ten geschenke ontvangen uit de nalatenschap van Mr. S. C. J. W. van Musschenbroek, Maart 1909 , zijn ook eenige Javaansche brieven, o. a. een verzoek van een tolk uit Ambarawa, om schoolmeester te worden, een brief van eene Raden Aju en een brief, waarbij een geschiedenis van Prambanan aangeboden wordt. Deze geschiedenis is $6 \mathrm{blz}$. van $26^{\circ}$ regels groot, in folio formaat $(34 \times 21 \mathrm{cM}$.) en bevat in lakon-vorm de bekende geschiedenis van Prabu Baka, Bandung en Lårå Djunggrang, die in steen verandert, geschreven 
in 1869. Verder bevat deze bundel 6 blz. over het JavaanschSundasche alphabet met Javaansche toelichtingen en twee Sundasche samenspraken en $14 \mathrm{blz}$. namen van boomen, personen, rangen en titels, maten, dieren en grondsoorten, in Kråmå en Ngoko, in Jav. karakter, met transcriptie van de Ngoko-woorden.

$$
\begin{gathered}
\text { XXX. } \\
\text { Primbon (HS. 249). } \\
22 \times 17 \text { cM., } 4 \text { blz. } 19 \text { r. }
\end{gathered}
$$

Dit HS. bevat geneesmiddelen (tamba), een Primbon těnung (wichelaarsboek) en een Sirěpan maling (tooverspreuk, door dieven gebruikt, om de lieden, die zij willen bestelen, in slaap te maken), met een afschrift in Javaansch karakter.

XXXI.

HS. 250 .

$$
34 \times 22 \text { cM., } 44 \text { blz. }
$$

Antwoorden op vragen van een resident over beambten, hun tractement, hunne rangen en titels, over wet- en fiqh-boeken, over de rechtspleging, over gebruiken bij geboorte, besnijdenis, huwelijk en begrafenis en over de garěběg's. De laatste 20 blz. bevatten een afschrift van de eerste 24 .

\section{XXXII.}

Kintaka sẹṇ̣on langěn swara (HS. 548). $34 \times 21$ c.M., 10 blz., 28 r.

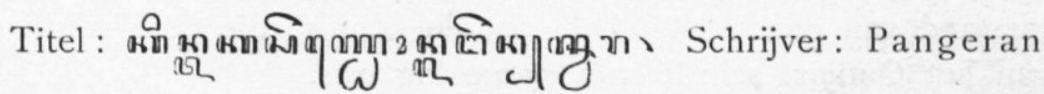
Adipati Arya Mangku Něgara IV.

De inhoud van dit HS. bestaat uit 4 verbasterde Oudjav. verzen, die gebruikt worden bij de langěn driya-voorstellingen eene wajang-soort, die door dezen prins is uitgevonden en die begeleid wordt door de gamelan salendro. Het repertoire is hier niet ontleend aan den Damar Wulan, zooals men zou meenen uit Veth, IV, 225, doch aan het Bhāratayuddha. Over den schrijver vergelijke men overigens: Dr. G. A. J. Hazeu, Bijdrage tot de kennis van het Jav. tooneel. pag. 97.

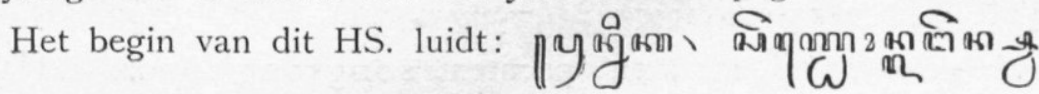




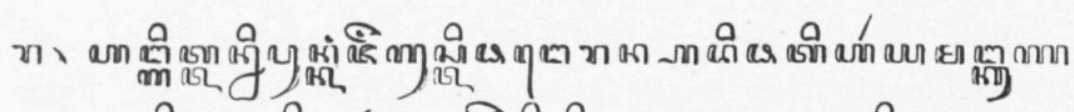

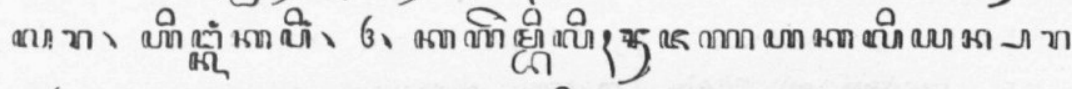

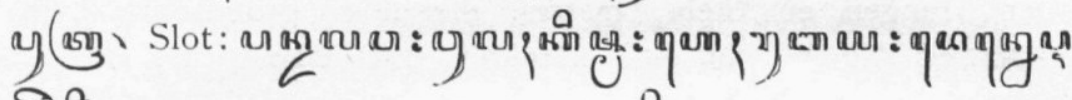

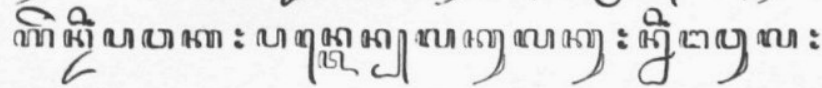

\section{XXXIII.}

Astrologie (HS. 622). $33 \times 22$ c.M., 42 blz.

Copie van een of meer oudere handschriften op lontar of daluwang van astronomisch-astrologischen aard, aangetroffen in Cornets de Groot, Statistiek van de residentie Grissee, 1822, met afbeeldingen. De eerste 28 blz. zijn het net exemplaar, de 13 volgende gemerkt a $1-\mathrm{a} 13$, een andere (klad) copie, die iets meer geeft of voor een gedeelte de verklaring van enkele teekeningen in het net exemplaar niet zoo volledig toelicht. Inliggend de brief, waarbij Cornets de Groot deze teekeningen aan het Kon. Instituut v. Taal- Land- en Volkenkunde aanbiedt. Op blz. 42, gemerkt b 1 , een Oud-Jav. alphabet met NieuwJav. toelichting, naar men gissen mag het alphabet, waarin het origineel dezer copie geschreven was.

De teekeningen op de eerste bladzijden stellen de teekenen van den dierenriem voor (vgl. Raffles pl.) Verder vindt men afbeeldingen van de wuku's, de Indische goden, enz. Uit den toestand van den tekst blijkt, dat de kennis, die de afschrijver van het Oudjav. schrift had, gebrekkig was.

\section{XXXIV.}

Sĕrat wěwangsulan pĕndangon sangking ing Pakualaman. (HS. 589).

$$
33 \times 22 \text { cM., } 7 \text { blz. }
$$

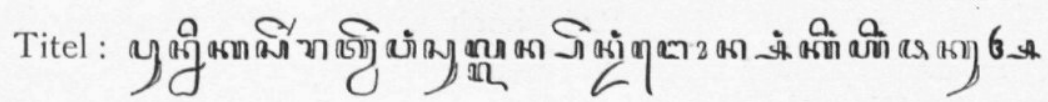

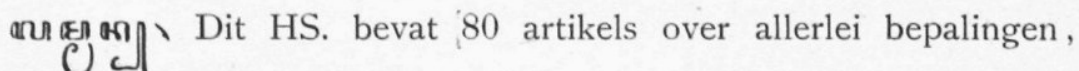
over geldsoorten, markten, pachten, songsong's, enz. 
XXXV.

Liedjes. (HS. 637).

$17 \frac{1}{2} \times 30 \frac{1}{2}$ c.M., 21 blz., 8 r.

De titel van dit HS., dat in 1904 van den Heer H. L. Ch. te Mechelen ontvangen werd, luidt:

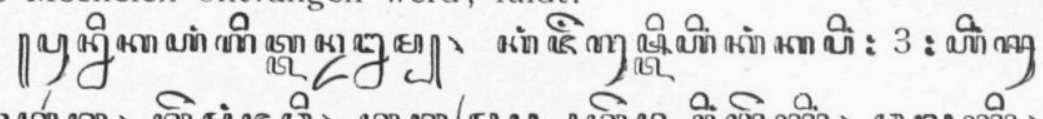
ท ผ

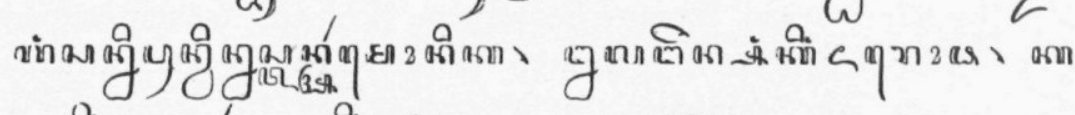

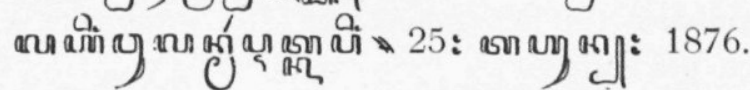

Het is eene verzameling Javaansche verzen, vervaardigd door Susuhunan Pakubuwana IV van Solo, om begeleid te worden door de harmonica. Gedateerd 25 Maart 1876.

\section{XXXVI.}

Samenspraken (HS. 638), $20 \frac{1}{2} \times 16 \frac{1}{2}$ c.M., 188 blz., 22 r.

Tegelijk met het vorige H.S. is ook van den Heer H. L. Ch. te Mechelen ontvangen eene verzameling Javaansche samenspraken met Nederl. vertaling, beginnende met: "wie zijt gij

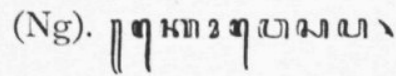

Achter in deel I, dat $43 \mathrm{blz}$. groot is, (aan den anderen kant begonnen) 25 blz. "vervormingen der Javaansche stamwoorden , in 35 artikels. Achter in deel III, dat 61 blz. groot is, 5 blz. Javaansche woorden met Nederl. vertaling.

\section{XXXVII.}

Geslachtslijst. (HS. 598).

$59 \times 45$ c.M., plano.

Genealogische lijst van overleden en nog levende Soerakartasche en Jogyakartasche vorsten. In het Javaansch met eene toelichting (vertaling) in het Nederlandsch. Vervaardigd te Soerakarta den 21 December 1842 door J. H. van der Palm.

\section{XXXVIII.}

HS. 609 .

$97 \times 65$ c.M., plano.

Plattegrond-teekening van de alun-alun te Soerakarta, om de 
opstelling van de aanwezigen bij gelegenheid van eene rampok-partij te veraanschouwelijken, met Jav. toelichtingen. Voor de namen der kanonnen vgl. men Not. Bat. Gen. XXVI (1888), blz. 64 (mededeeling van den heer G. P. Rouffaer).

\section{XXXIX.}

Krissenboek. (HS. 645).

$32 \times 20$ c.M. , 105 blz.

Afbeeldingen van Javaansche wapens (krissen, pieken enz.) in het rijk Soerakarta in gebruik. Vervaardigd op last van den Susuhunan van Soerakarta. In het geheel zijn 158 wapens met de pen geteekend en gekleurd.

Voorin staat: "Dit boek is op last van den Soesoehoenan (keizer) van Soerakarta in den kraton (paleis) aldaar vervaardigd en aan den ondergeteekende door Hoogstdenzelve overhandigd, bevattende de namen van alle krissen, pieken enz. in genoemd Rijk van Soerakarta op Java in gebruîk. Voor de waarheid de Vice-President van den Raad van Ned. Indië V. F. W. van Net.»

De namen worden in Jav. karakter en transcriptie gegeven, eerst die van lansen, daarna die van krissen. Achterin een lijst van namen van pamor op de lemmeten van krissen, lansen, sabels enz., in Javaansch karakter met transcriptie, doch zonder af beelding.

\section{XL.}

Krissenboek (HS. 557).

$35 \frac{1}{2} \times 21 \frac{1}{2}$ c.M., 23 vellen.

Teekeningen van Javaansche krissen en lansen, met opgave van de namen in 't Javaansch in Jav. schrift en daarbijgevoegde transcriptie in Latijnsche letters. De herkomst is niet bekend.

\section{XLI.}

Inscriptie (HS. 244).

Transcriptie van eene O. Jav. inscriptie, die begint met: $\mathrm{O} \dot{\mathrm{m}}$ awighnam astu Çaka warṣātīta 813. De linkerzijde bevat 15, het midden 14, de rechterzijde 15 en de achterkant 18 regels. De herkomst is onbekend. Vgl. ook het volgende HS.

\section{XLII.}

Inscriptie. (HS. 242.)

$31 \frac{1}{2} \times 20$ cM., 4 blz.

Proeven van Kawi met interlineaire vertaling in het Javaansch, 
herkomstig van N. Engelhard, afgestaan door W. F. E. M. van Alphen in 1852.

Dit blijkt dezelfde inscriptie van 813 Çāka te zijn, waarvan HS. 244 (XLI) eene transcriptie bevat.

De inscriptie in zwarten inkt, daaronder eene transcriptie in rooden inkt en daaronder de Jav. vertaling. Zoowel de transcriptie als de vertaling zijn onbetrouwbaar. Het jaartal bijv. wordt getranscribeerd met 1234 , terwijl er duidelijk 813 staat. De eerste woorden: Om் awighnam astu worden vertaald met: ใิ ชิ ตा ศा

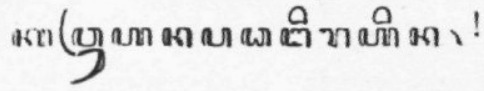

\section{XLIII.}

Inscriptie. (HS. 554).

Photographische afbeelding in 2 bladen van de door den heer H. C. Humme in Bijdr. T. L. en Vk. $4^{\text {e }}$ volgr. VIII, p. $1-20$ uitgegeven piagěm van Bantěn of van dien van Palembang (Bijdr. T. L. Vk. $4^{\text {e }}$ volgr. X. p. 363-369).

AFDEELING IX.

Lontarhandschriften.

XLIV.

Udyogaparwa. (HS. 503).

54 cM., 4-125 folia.

Tjakěpan. Eenige verschreven palmbladen, hier en daar afgeknaagd, eenige palmbladen afgebroken, andere doorgebroken. Het begint met het Sanskṛtvers $43^{\text {b}}$ : phalāphalawatī çākhe yathaikasmin wanaspatau, waarmede ook de HSS. van het Udyogaparwa te Leiden en te Batavia aanvangen. Aan het slot is sprake van ṛ̣̦i Gālawa, den leerling van Wiçwāmitra, voor wien hij 800 paarden met een bijzonder soort haren moest zoeken (Van der Tuuk, Kawi-Bal. Wdb. IV, 757, s. v. Gālawa). Deze geschiedenis wordt in den Sanskṛt-tekst verhaald in adhyāya 105-118 (pag. 224-235 der Calcutta-uitgave). Daar het Udyogaparwa in den Sanskṛt-tekst 197 adhyāya's bevat, ziet men, dat een groot gedeelte van den Oudjav. tekst ontbreekt. Over andere HSS. van het Oudjav. Udyogaparwa te Leiden en te Batavia vgl. Vreede's Cat. der Jav. en Mad. HSS. p. 388, mijn Supplement op den Cat. der Jav. en Mad. HSS. 
II, p. $153--155$ en mijn proefschrift: Drie boeken van het Oudjav. Mahâbhârata, pag. $17-23$. Verder vergelijke men mijne verhandeling over het Udyogaparwa hierboven pag. 219—296.

\section{XLV.}

Sārasamuçcaya. (HS. 504).

49 cM., 90 folia.

Tjakępan. Bij dit HS. is een palmblad gevoegd, dat er oorspronkelijk niet bij behoort, daar het een fragment uit het laatste gedeelte van het $\bar{A}$ diparwa bevat, waarin de brand van het Khāṇdawa-woud beschreven wordt, overeenkomende met pag. 206 , r. 21 tot pag. 208 , r. 7 mijner uitgave van dit parwa ('s Gravenhage, 1906).

De Sārasamuçcaya is eene compilatie van zedekundige spreuken, voornamelijk uit het Anuçāsanaparwa, waarover men vgl. Friederich, Voorloopig Verslag van het eiland Bali, pag. 22, $\mathrm{n}^{\circ} 4$ en mijne verhandeling: Eene Oudjavaansche vertaling van Indische spreuken (Bijdr. T. L. Vk. $6^{c}$ volgr. VIII, pag. 393-398). Den naam Sārasamuçcaya en Nawaruci vindt men op de schutbladen en het etiket terug. Dit HS. is incompleet. Het loopt ongeveer even ver door als het Bataviasche HS. 860, beschreven in mijn Suppl. op den Cat. der Jav. en Mad. HSS. II, pag. 276 (cod. MDCLXXI), doch hier wordt ook nog een fragment van het volgende Sanskṛt-vers aangehaald:

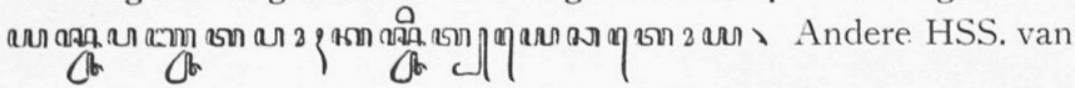
deze spreukenverzameling te Leiden en te Batavia zijn beschreven in mijn bovengenoemd Suppl. op den Cat. der Jav. en Mad. HSS. II, pag. 275-277.

XLVI.

Primbon. (HS. 508).

\pm 31 cM., 119 folia.

Tjakěpan. De palmbladen van verschillende lengte. De inhoud bestaat hoofdzakelijk uit tooverspreuken (mantra), o. a. sang hyang Paramarahasya (het hoogste geheim), sang hyang Agnirahasya, sang hyang Upadeçarahasya (fol. 13), krama ning yoga, mantra ning asabuk putih (fol. 9), mantra pasabukan atuwatu. Over het algemeen komen deze tooverspreuken overeen met die in de Leidsche Universiteits- 
bibliotheek en van het Batav. Genootschap, beschreven in mijn Supplement op den Cat. der Jav. en Mad. HSS. II, pag. 321384. Het eerste palmblad is van boven beschadigd, draagt het

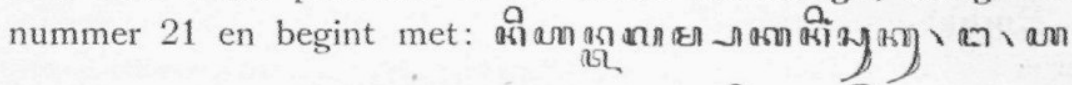

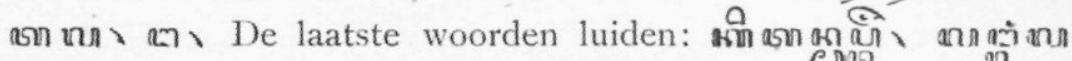

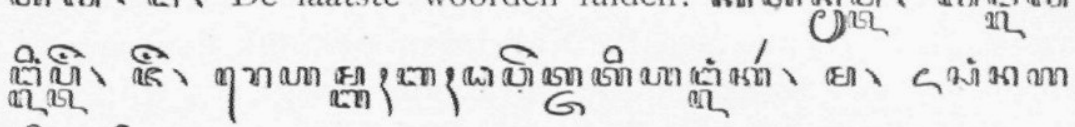

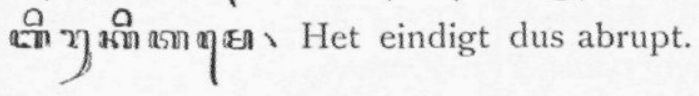

\author{
XLVII. \\ HS. 507. \\ $32 \frac{1}{2}$ cM., 39 folia.
}

Tjakępan, in buda-schrift. Begin: Ana kidung rame utama ramene. Vgl. de Bataviasche en Leidsche HSS. in dit schrift. De taal is dus modern, doch het schrift oud. Op het schutblad het merk G 20. Dit HS. is afkomstig uit Kědoe. Het is een geschenk van J. C. Baud.

\title{
II. BALINEESCHE HANDSCHRIFTEN.
}

\section{XLVIII.}

Lingga pettak. (HS. 505).

$$
47 \text { cM., } 6 \text { folia. }
$$

Ěmbat-ĕmbatan. Dit is de redactie, die door J. de Vroom uitgegeven is onder den titel: Hi Lingga p'ta (Balineesch volksgedicht) in Tijdschr. Ind. T. L. Vk. XXI, pag. 403-446 en pag. 534-597. Ter vergelijking met die uitgave geven wij hier eene transcriptie van het eerste vers van dit HS.:

Ada kidung gaguritan

djinada aniru gẹṇịing

gumrĕg ring buddha kaliwon

tanggal ping pat ș̣̌k dalu

çaçih kalima rah lima

kihun riris těnggěk pitu duknya nurat.

Het loopt door tot Lingg a pețak's dood (in de Vroom's editie vers 47). Het laatste palmblad is beschadigd. Vgl. de beschrijving der Leidsche HSS. van dit gedicht in mijn Suppl. op den Cat. der Sund. HSS. en Cat. van de Bal. en Sasaksche HSS. pag. 115-116.

Dl. 69. 


\section{XLIX.}

Brieven. (HS. 615).

Ěmbat-ěmbatan, 3 folia, van 20,22 en $24 \frac{1}{2}$ cM. De eerste brief is van Tihang Gẹ̣é Padang aan Penungsiman en handelt over eene kip en over een prauw. In den tweeden brief vraagt Gẹdé Dyaka aan Pa Nursiman een stuk ijzer, om er een beitel van te maken. De derde brief draagt een tjap van Anak Agung i dewa Nglurah Gẹdé Putu, dîe een met padi beladen schip schenkt aan Pan Kënas.

\section{MADUREESCHE HANDSCHRIFTEN.}

L.

Woordenlijst. (HS. 640).

$21 \times 16$ cM., 19 blz., 24 r.

Woordenlijst in drie kolommen: Maleisch, Madureesch en Kambang. Naast de Mal. woorden in het begin met rooden inkt Mak. woorden. Het Madureesch in Jav. karakter, overigens alles in transcriptie. Het eerste woord is :

\begin{tabular}{|c|c|c|}
\hline $\begin{array}{l}\text { Melajoe } \\
\text { kepala }\end{array}$ & $\begin{array}{l}\text { Mak. } \\
\text { oeloe }\end{array}$ & 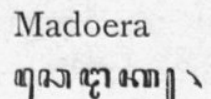 \\
\hline
\end{tabular}

Onderaan met rooden inkt eene aanteekening van den heer H. N. Kiliaan, gedateerd 1895 :

"De taal der Kambangers blijkt geen dialect van het Madoereesch te zijn, zoodat ze niet mede beoefend behoeft te worden door den controleur à la suite.»

Van den Controleur H. N. Kiliaan. Ontvangen in 1905.

LI.

Woordenlijsten en samenspraken. (HS. 559).

$34 \times 22$ cM., 77 blz., 28 r.

Op den omslag staat "Madoereesche taal». Woordenlijsten en samenspraken, gedeeltelijk met Maleische, gedeeltelijk met Javaansche of Nederlandsche toelichtingen. 
NUMMERS DER HANDSCHRIFTEN

met volgnummers en bladzijden in den catalogus.

\begin{tabular}{|c|c|c|c|c|c|c|c|}
\hline & 237 & $\mathrm{n}^{\circ} \quad$ VIII & bl. & 395 & HS. 552 & $n^{\circ} \quad X I$ & bl. 39 \\
\hline & $237^{a}$ & , IX & ", & 395 & , 554 & , XLIII & , 411 \\
\hline & 239 & , XII & , & 397 & 556 & ,, XXIV & 405 \\
\hline & 42 & ,, XLII & , & 410 & 557 & , XL & , 410 \\
\hline & & , I & , & 387 & 559 & , LI & , 414 \\
\hline & 44 & ,, XLI & , & 410 & 562 &, $\mathrm{X}$ & 96 \\
\hline & $48^{\mathrm{a}}$ & , XXIII & ," & 40 & 564 & , XX & \\
\hline & $248^{b}$ & , XXII & ," & 40 & , 566 &, II & , : \\
\hline & $48^{c}$ & , XXVI & ,, & 40 & , 567 & , VI & \\
\hline & 49 & , XXX & ," & & 583 & ," XXVIII & , \\
\hline & 250 & , XXXI & ,, & & 585 &,, III & , \\
\hline & 421 & , XVI & , & 400 & 589 & „, XXXIV & , \\
\hline & 22 & ,, XVII & ," & & 598 & , XXXVII & , \\
\hline & 503 & , XLIV & ," & & 606 & ,, IV & ., \\
\hline & 504 & , XLV & ," & 41 & 609 & , XXXVIII & ," \\
\hline & 505 & , XLVIII & , & 41 & 615 & „, XLIX &, \\
\hline & 507 & „, XLVII & , & & 619 & ,, XIV & , \\
\hline & 508 & ,, XLVI & ,, & 41 & , 622 & , XXXIII &, \\
\hline & 519 &, VII & , & 391 & 636 &, XVIII &, \\
\hline & 520 &, $\mathrm{~V}$ & ," & 38 & 637 & , XXXV & , \\
\hline & 521 & , XIII & ," & 39 & 638 & , XXXVI & , 409 \\
\hline & 522 & , XV & , & 39 & 639 & , XXI & , 40 \\
\hline & 523 & , XXV & ," & & 640 &, $\mathrm{~L}$ & $"$ \\
\hline & 539 & ,, XXVII & , & 40 & , & , XXIX & , 406 \\
\hline & 548 & , XXXII & ," & 40 & 645 & , XXXIX & , 410 \\
\hline & נקו & „, XIX & & & & & \\
\hline
\end{tabular}




\section{ALPHABETISCHE INDEX DER HANDSCHRIFTEN.}

Adji Saka .

HS. 567.

Ardjuna wiwaha . . . . „ 243.

Astrologie . . . . . . . , , 622 .

Babad Dipa Něgara . . . . , 521.

Babad Kartasura . . . . . „5 522 .

Babad Sěngkala . . . . , , 619.

Babad Tanah Djawi . . . . , 237, 237ª 562.

Babad těmbang . . . . . . , 239, 552.

Basudewa . . . . . . . . , 520 .

Brieven . . . . . . , $248^{\circ}, 539,583,615,641$.

Damar Wulan . . . . . . „ 636.

Djaka Salewah . . . . . . , 551.

Geslachtslijst . . . . . . . „ 598.

Hadji Ripangi . . . . . „ $248^{\mathrm{b}}$.

Inscripties . . . . . . . . , 242, 244, 554.

Javaansche wetten . . . . , $248^{\mathrm{a}}$.

Javaansche woordenboeken . . " 523, 556.

Kintaka sẹṇdon langěn swara . , 548.

Krissenboeken . . . . . ” 557, 645.

Liedjes . . . . . . . . . „ 637.

Lingga pẹțak. . . . . . . , 505.

Menak Sațit . . . . . . . , 519.

Miscellanea . . . . . . , 250, 507, 609.

Ngelmi Makripat sědjati . . , , 639.

Palasara . . . . . . . . , 564.

Pandawa rare . . . . . . , 243.

Pandji gandrung Angreni . . , 421.

Pandji klajan Tundjung Seta . „ 422.

Primbon . . . . . . . . „ 249, 508.

Rama . . . . . . . ” 566, 585, 606.

Samenspraken . . . . . . , 638.

Sārasamuçcaya . . . . . . , 504.

Serat wěwangsulan pěndangon sangking ing Pakualaman HS. 589.

Udyogaparwa . . . . . . . . . . . . . . „ 503.

Woordenlijst . . . . . . . . . . . . . . " 640 .

Woordenlijsten en samenspraken. . . . . . . " 559. 


\section{N H O U D.}

JAVAANSCHE HANDSCHRIFTEN.

AFDEELING I.

Epische geschriften.

Bladz.

Paṇdawa rare en Ardjuna Wiwaha (I) . . . .. . . . . 387 Rama (II-IV) . . . . . . . . . . . . . . 388-389 Basudewa (V) . . . . . . . . . . . . . . . . . 389

AfDeELING II.

Mythologie en legendarische geschiedenis.

Adji Saka (VI). . . . . . . . . . . . . . . . 391 Menak Sațit (VII). . . . . . . . . . . . . . 391

Afdeeling III.

Geschiedenis.

Babad Tanah Djawi (VIII-X) . . . . . . . 395-396 Babad těmbang (XI-XII) . . . . . . . . . .396-397 Babad Dipa Nĕgara (XIII) . . . . . . . . . . . . 398 Babad Sengkala (XIV) . . . . . . . . . . . . . 398 Babad Kartasura (XV) . . . . . . . . . . . ‘ . 399

AFdeELING IV.

Romantische Verhalen.

Pandji gandrung Angreni (XVI) . ... . . . . . . 400 Pandji klajan Tundjung Seta (XVII) . . . . . . . 401 Damar Wulan (XVIII) . . . . . . . . . . . . . 401 Djaka Salewah (XIX). . . . . . . . . . . . . . 402

AfdeELing V.

Dramatische werken.

Palasara $(\mathrm{XX})$. . . . . . . . . . . . . . . 403

AfDEeling VI.

Godsdienstige werken.

Ngelmi Makripat sědjati (XXI) . . . . . . . . . 403 Hadji Ripangi (XXII). . . . . . . . . . . . . 404 
AfDeELING VII.

Bladz.

Wetboeken.

Javaansche wetten (XXIII) .

AFDEELING VIII.

Varia.

Javaansche woordenboeken (XXIV-XXV) . . . . . 405

Brieven (XXVI-XXIX). . . . . . . . . . . . 406

Primbon $(\mathrm{XXX})$. . . . . . . . . . . . . . 407

Beantwoording van vragen van een resident (XXXI). . . 407

Kintaka sẹṇdon langěn swara (XXXII). . . . . . . . 407

Astrologie (XXXIII) . . . . . . . . . . . . . . 408

Serat wěwangsulan pěndangon sangking ing Pakualaman

(XXXIV) . . . . . . . . . . . . . . . . . 408

Liedjes (XXXV) . . . . . . . . . . . . . . . . . 409

Samenspraken (XXXVI). . . . . . . . . . . . . 409

Geslachtslijst (XXXVII) . . . . . . . . . . . . 409

Plattegrond-teekening (XXXVIII). . . . . . . . . . 409

Krissenboeken (XXXIX-XL). . . . . . . . . . . 410

Inscripties (XLI-XLIII) . . . . . . . . . . 410-411

AFDEELING IX.

Lontarhandschriften.

Udyogaparwa (XLIV) . . . . . . . . . . . . . . 411

Sārasamuçcaya $(\mathrm{XLV})$. . . . . . . . . . . . . . . . 412

Primbon (XLVI) . . . . . . . . . . . . . . . . 412

Kidung (XLVII) . . . . . . . . . . . . . . . 413

II. BALINEESCHE HANDSCHRIFTEN.

Lingga pĕțak (XLVIII) . . . . . . . . . . . . . 413

Brieven (XLIX). . . . . . . . . . . . . . . 414

III. MADUREESCHE HANDSCHRIFTEN.

Woordenlijst (L) . . . . . . . . . . . . . . . 414

Woordenlijsten en samenspraken (LI) . . . . . . . 414 